\title{
NOTES
}

\section{GOVERNMENT CONSENT TO WAIVER OF JURY TRIAL UNDER RULE 23(a) OF THE FEDERAL RULES OF CRIMINAL PROCEDURE*}

The Sixth Amendment to the Federal Constitution guarantees defendants in federal criminal proceedings the right to trial by an impartial jury. ${ }^{1}$ This right is one of many by which the Constitution attempts to insure a fair criminal trial in federal courts. ${ }^{2}$ By case law or statute an accused may elect to waive most of these rights. ${ }^{3}$ Rule 23 (a) of the Federal Rules of Criminal Procedure ${ }^{4}$ permits an accused to waive the right to jury trial and to elect

*United States v. Silverman, Crim. No. 9111, D. Conn., March 29, 1956.

1. "In all criminal prosecutions, the accused shall enjoy the right to a speedy and public trial, by an impartial jury of the State and district wherein the crime shall have been committed. . . " U.S. ConsT. amend. VI. Article III, $\S 2$, cl. 3 also provides for jury trial in all criminal cases except impeachment. These clauses are to be construed in pari materia, Callan v. Wilson, 127 U.S. 540, 549-50 (1888), and are not jurisdictional, Patton v. United States, 281 U.S. 276,298 (1930).

The right to trial by jury of the Federal Constitution does not extend to state proceedings. Betts v. Brady, 316 U.S. 455, 461 (1942). Nor does it apply to petty offenses. District of Columbia v. Clawans, 300 U.S. 617, 624-25 (1937). On the scope and application of the Sixth Amendment generally, see Heller, The Sixtr Amendarent 35-59 (1951).

2. These rights are particularly set out in the Fifth and Sixth Amendments. See Adams v. United States ex rel. McCann, 317 U.S. 269, 276, 279 (1942); cf. Chambers v. Florida, 309 U.S. 227, 236-37 (1940).

3. Case Lazo: Trono v. United States, 199 U.S. 521, 533-34 (1905) (double jeopardy); United States v. Murdock, 284 U.S. 141, 148 (1931) (self incrimination); Morland v. United States, 193 F.2d 297, 298 (10th Cir. 1951) (speedy trial) ; United States v. Sorrentino, 175 F.2d 721, 723 (3d Cir.), cert. denied, 338 U.S. 868 (1949) (public trial); Grove v. United States, 3 F.2d 965, 966-67 (4th Cir.), cert. dented, 268 U.S. 691 (1925) (confrontation of witnesses); Johnson v. Zerbst, 304 U.S. 458, 465 (1938) (assistance of counsel).

Statute: FED. R. CRR. P. 7(b) (grand jury indictment), United States v. Jones, 177 F.2d 476, 478 (7th Cir. 1949); FED. R. CRIM. P. 20 (venue), United States v. Gallagher, 183 F.2d 342, 346 (3d Cir. 1950), cert. denied, 340 U.S. 913 (1951), but see United States v. Bink, 74 F. Supp. 603 (D. Ore. 1947). See also FED. R. CRIM. P. 21 (a).

But the requirement of a unanimous verdict may not be waived. Hibdon v. United States, 204 F.2d 834, 836-38 (6th Cir. 1953) (unanimous verdict considered element of duc process); see FEo. R. CruMr. P. 31 (a). See generally Levine v. United States, 182 F.2d 556, 558-59 (8th Cir. 1950), cert. denied, 340 U.S. 921 (1951).

4. "Cases required to be tried by jury shall be so tried unless the defendant waives a jury trial in writing with the approval of the court and the consent of the government." FED. R. CRIMr. P. 23(a).

The rules were authorized by 54 STAT. 688 (1940), as amended, 18 U.S.C. $\$ 3771$ (1952) and became effective on March 21, 1946. They have the force and effect of statutes. Rattley v. Irelan, 197 F.2d 585, 586 (D.C. Cir. 1952); Ochoa v. United States, 167 F.2d 341, 345 
trial by the court alone. 5 But the rule requires court approval and government consent before waiver is permitted. Ordinarily government consent to waiver may be obtained as a matter of course, and until recently this feature of rule 23(a) had not met with challenge. However, the possibility of hostile juries in Smith Act ${ }^{6}$ prosecutions suggests that the requirement of government consent may clash with the basic purpose of the Sixth Amendment.

The constitutionality of the requirement of government consent to waiver was attacked in the recent case of United States $v$. Silverman. ${ }^{7}$ Defendants were indicted under the Smith Act for conspiracy to advocate the overthrow of the government by force and violence. Before trial, they moved to waive a jury and sought trial by the court. ${ }^{8}$ The government refused consent to the waiver. ${ }^{9}$ In support of the motion the defendants contended, in effect, that an accused has an unqualified right to waive a jury and that rule 23(a), by restricting that right, is therefore unconstitutional on its face. ${ }^{10}$ The defendants further maintained that in their case an impartial jury was unobtainable. ${ }^{11}$ An implicit premise of this argument was that the impartial jury requirement of the Sixth Amendment would be defeated if the government could withhold. consent to waiver. ${ }^{12}$ The government's refusal was based on a literal reading

(9th Cir. 1948). Promulgation by the Supreme Court did not foreclose consideration of their validity. Cf. Mississippi Publishing Corp. v. Murphree, 326 U.S. 438, 444 (1946) (Federal Rules of Civil Procedure); Baker v. United States, 139 F.2d 721, 723 (8th Cir. 1944).

5. Federal trial courts are empowered to try criminal cases without a jury. See Patton v. United States, 281 U.S. 276, 298 (1930) ; Schick v. United States, 195 U.S. 65, 71 (1904).

6. 18 U.S.C. $\$ 2385$ (1952).

7. Crim. No. 9111, D. Conn., March 29, 1956, notice of appeal filed, 2d Cir., April 20, 1956. This is apparently the first case in which the rule's requirement of government consent to waiver has been challenged. Subsequent to the motion for waiver of jury trial in Silvcrman, a similar motion was made by defendants in another Smith Act case, United States v. Brandt, Crim. No. 21276, N.D. Ohio, Feb. 10, 1956. Upon government refusal to consent, the court orally denied defendants' motion for waiver stating that rule 23 (a) was constitutional. Letter from Hon. Charles J. McNamee, United States District Judge, N.D. Ohio, April 11, 1956, and letter from Fred $\mathrm{H}$. Mandel, attorney for defendants in Brandt, April 12, 1956, to the Yale Law Journal, on file in Yale Law Library. See Cleveland Plain Dealer, Feb. 11, 1956, p. 1, col. 3.

S. The motion was filed on Sept. 22, 1955. Memorandum of Decision on Defendants' Motion for Waiver of Jury Trial, p. 1, Oct. 3, 1955, United States v. Silverman (hereinafter cited as Silverman Memorandum).

9. Silverman Memorandum, p. 2; Transcript of Proceedings held on Sept. 30, 1955, in Connection with Defendants' Motion to Waive Right to Trial by Jury, pp. 25-26, 28-29, United States v. Silverman (hereinafter cited as Transcript); Brief for United States on Question of Defendants' Motion for Waiver of Jury Trial, United States v. Silverman.

10. Silverman Memorandum, p. 1; Defendants' Brief on Motion to Waive Trial by Jury, pp. 3-4, United States v. Silverman (hereinafter cited as Defendants' Brief); Transcript, pp. 12, 22, 23.

11. Silverman Mfemorandum, p. 1; Defendants' Brief, p. 4 ; Transcript, pp. 13-14, $19-21$.

12. The defendants actually argued that the inability to obtain an impartial jury would prevent a fair trial, thus denying due process under the Fifth Amendment. Defendants' Erief, p. 4. This Note discusses this problem as a possible violation of the impartial jury 
of rule 23(a), which it urged allowed consent to be arbitrarily withheld.13

The court denied the defendants' motion. ${ }^{14}$ Although recognizing that arguments existed for allowing an accused alone to determine the mode of trial, the court stated that rule 23(a) had the force of a statute and that it unconditionally required government consent. ${ }^{15}$ The court also held that the rule was not unconstitutional, but it did not discuss the constitutional arguments raised by the defendants.

The defendants' argument that they had an unqualified right to waive a jury is unsupported either by case law or by logical analysis of the constitutional right to jury trial. The defendants incorrectly relied on the Supreme Court's opinion in Patton $v$. United States ${ }^{16}$ for judicial authority that an unqualified right of waiver exists. In Patton the Court held that an accused could be tried by a jury of eleven when government and defense, with court approval, agreed that the trial should continue after a juror became ill. ${ }^{17}$ The Court clearly indicated that waiver of trial by twelve jurors was equivalent to waiver of a jury entirely. ${ }^{18}$ Patton, however, did not decide whether a defendant has an unqualified right to waive a jury. Admittedly, language in the opinion declares that the decision to waive a jury should rest entirely with an accused.19 But nothing in the decision supports the existence of an accused's right to be the

provision of the Sixth Amendment. Denial of this Sixth Amendment guarantee is also a denial of due process under the Fifth Amendment. See Baker v. Hudspeth, 129 F.2d 779, 781 (10th Cir.), cert. denied, 317 U.S. 681 (1942).

13. See note 9 supra.

14. Silverman Memorandum, pp. 2-3. Following denial of the motion for waiver, the defendants brought a civil action against the trial judge and the United States District Attorney. They sought an injunction to prevent trial by jury and requested the convening of a three judge court under the provisions of 28 U.S.C. $\$ \$ 2282,2284$ (1952) to determine the constitutionality of rule 23 (a). A government motion for dismissal was granted on the ground that the constitutional question could be determined in the criminal action itself. Memorandum of Decision on Motion to Dismiss, Silverman v. Cohen, Civil No. 5783, D. Conn., Oct. 14, 1955. Trial of the original action before a jury began on Nov. 3, 1955. On March 29, 1956, the jury found six defendants guilty, one not guilty, and was unable to reach a verdict on the eighth. New Haven Evening Register, Nov. 3, 1955, p. 1, col. 1 and March 30, 1956, p. 1, col. 2.

15. Silverman Memorandum, pp. 2-3.

16. 281 U.S. $276(1930)$.

17. Id. at 312-13. See Fowler v. Hunter, 164 F.2d 668, 670 (10th Cir. 1947), ccrt. denied, 333 U.S. 868 (1948) (jury of ten); Taylor v. United States, 142 F.2d 808, 816 (9th Cir.), cert. denied, 323 U.S. 723 (1944) (jury of eleven). FED. R. CRInr. P. 23(b) (parties may stipulate with court approval that jury shall consist of any number less than twelve).

For history of jury waiver in federal courts up to Patton, see Grant, Waizer of Iury Trials in Felony Cases, 20 CaLIF. L. Rev. 132, 147-56 (1932).

18. 281 U.S. at 290 . Hence trial by jury has been permitted to be waived with government consent and court approval. Spann v. Zerbst, 99 F.2d 336 (5th Cir. 1938); Ferracane v. United States, 47 F.2d 677, 679 (7th Cir. 1931).

19. The provisions for jury trial were "meant to confer a right upon the accused which he may forego at his election. To deny his power to do so, is to convert a privilege into an imperative requirement." 281 U.S. at 298 . See also $i d$. at $296,305,308$. 
sole judge of the mode of trial. On the contrary, a dictum states that government consent is needed for waiver. ${ }^{20}$ This dictum has been followed by lower federal courts to reject the existence of an unqualified right of an accused to waiver ${ }^{21}$ and in fact was the basis for rule 23 (a)..$^{22}$

Nor does the Sixth Amendment right to jury trial establish the existence of a defendant's unqualified right to waive a jury. The right to jury trial means only that a defendant has a privilege not to be subjected against his will to another form of trial. It does not mean he has a right to choose that different form. ${ }^{3}$ True, federal courts have allowed defendants to waive rights similar to the right of trial by jury. ${ }^{24}$ But in none of these instances was the decision based on any constitutional right of waiver.

While rule 23(a) is not unconstitutional on its face, a reading of the rule which makes government consent mandatory may violate the Sixth Amendment guarantee of an impartial jury by forcing a Smith Act defendant to trial before a biased jury when he has sought trial by the court. Three devices to counter bias ${ }^{25}$ in the jury are available to an accused who believes an impartial jury is unobtainable in the district of trial because considerable animosity has been manifested against him. He may request a change of venue, ask for a continuance, ${ }^{26}$ or accept trial in the district and rely on the voir dire

20. "In affirming the power of the defendant . . . to waive a trial by ... jury . . . we do not mean to hold that the waiver must be put into effect at all events. . . Not only must the right of the accused to a trial by a constitutional jury be jealously preserved, but the maintenance of the jury as a fact finding body in criminal cases is of such importance and has such a place in our traditions, that, before any waiver can become effective, the consent of government counsel and the sanction of the court must be had, in addition to the express and intelligent consent of the defendant." 281 U.S. at 312.

21. C.I.T. Corp. v. United States, 150 F.2d 85, $91-92$ (9th Cir. 1945) ; Rees v. United States, 95 F.2d 784, 790-91 (4th Cir. 1938); United States v. Dubrin, 93 F.2d 499, 505 (2d Cir. 1937), cert. denied, 303 U.S. 646 (1938).

22. See advisory committee note to rule $23(\mathrm{a})$ and Longsdorf, The Beginnings of Federal Criminal Procedure 44, in 4 Barron, Federal Practice and Procedure (1951).

23. See Palmer v. State, 195 Ga. 661, 669, 25 S.E.2d 295, 301 (1943) ; People v. Scornavache, 347 I1l. 403, 414-16, 179 N.E. 909, 913-14 (1931); Commonwealth v. Miller, 289 Mass. 441, 465, 194 N.E. 463, 474-75, cert. denied, 295 U.S. 765 (1935). But see People v. Scornavache, supra at $420-21,179$ N.E. at 915 (dissenting opinion).

24. See note 3 supra.

25. "Bias" and "prejudice" are often used interchangeably. See, e.g., United States v. Valenti, 120 F. Supp. 80, \$3-S7 (D.N.J. 1954) ; Stevens v. State, 94 Okla. Crim. 216, 22125, 232 P.2d 949, 955-59 (1951) ; Durham v. State, 182 Tenn. 577, 584-87, 188 S.W.2d 555, 558-59 (1945); Haslam v. Morrison, 113 Utah 14, 20, 190 P.2d 520, 523 (1948). But see Thoxipson \& Mierrianx, Juries $\$ 191$ (1882). In this Note both terms are employed to mean a hostility toward one of the parties that produces a "predisposition to decide a cause or issue in a certain way, which does not leave the mind perfectly open to conviction." Black, Law Dictionary 205, 1343 (4th ed. 1951). See Busch, Law and Tactics in Jury Trisls $\$ 117$ (1949); 1 Thonspson, Trials $\S 72$ (Early ed. 1912).

26. FED. R. CRIS. P. 21 (a) provides for change of venue on defendant's motion if the court is satisfied that prejudice against the defendant precludes a fair and impartial trial in the district. See United States v. Parr, 17 F.R.D. 512, 518-20 (S.D. Tex. 1955) (hostile publicity); United States v. Florio, 13 F.R.D. 296 (S.D.N.Y. 1952) (same). But trial 
to eliminate prejudiced jurors. Change of venue is practicable only if hostility against an accused will be reduced by removal of trial to another district. And continuance is effective only if it may be expected that bias against an accused will subside in a reasonable time. ${ }^{27}$ In Smith Act prosecutions, however, change of venue and continuance are ineffective to assure an impartial jury. Courts have recognized that nationwide hostility exists against persons indicted under the act. ${ }^{28}$ Extensive evidence corroborates this view. ${ }^{20}$ And no

courts are reluctant to grant a motion for transfer, and the determination is within their sound discretion. See, e.g., Reynolds v. United States, 225 F.2d 123, 128-29 (5th Cir.), cert. denied, 350 U.S. 914 (1955) ; Callanan v. United States, 223 F.2d 171, 177 (8th Cir.), cert. denied, 350 U.S. 862 (1955).

While the federal rules do not specifically provide for continuance, courts will postpone trials because of prejudicial publicity. See Delaney v. United States, 199 F.2d 107, 111-16 (1st Cir. 1952), 53 Colun. L. Rev. 651 (1953). However, courts are also reluctant to grant a continuance, the denial of which is within their sound discretion. Compare Delaney v. United States, supra, with Schino v. United States, 209 F.2d 67, 70 (9th Cir.), cert. denied, 347 U.S. 937 (1954); see Brown v. United States, 228 F.2d 286, 287 (5th Cir. 1955).

27. Courts will not postpone trials indefinitely. See, e.g., Allen v. United States, 4 F.2d 688, 698 (7th Cir. 1924), cert. denied, 267 U.S. 597 (1925) (cause for continuance "would have doubtless been as impressive at a later date as it was at the time of the trial") ; cf. United States v. Von Clemm, 136 F.2d 968, 971 (2d Cir.), cert. denied, 320 U.S. 769 (1943) (refusal to postpone trial until after war). See note $30 \mathrm{infra.}$

28. E.g., "[I]t is urged that it was impossible ... to get an impartial jury because of the heated public feeling against Communists. That such feeling did exist among many persons-probably a large majority-is indeed true. ..." United States v. Dennis, 183 F.2d 201, 226 (2d Cir. 1950), aff'd, 341 U.S. 494 (1951). See United States v. Flynn, 216 F.2d 354, 373-74 (2d Cir. 1954), cert. denied, 348 U.S. 909 (1955) ; United States v. Mesarosh, 223 F.2d 449, 457-58, 459-60 (3d Cir.), cert. granted, 350 U.S. 922 (1955).

Admittedly the hostility is against Communists. But Smith Act defendants are popularly identified as Communists, and no defendant in a Smith Act trial since 1949 has testified he was not a member of the Communist Party. Letter from William F. Tompkins, Assistant Attorney General, United States Dep't of Justice, to the Yale Lazv Journal, March 23, 1956, on file in Yale Law Library. Consequently the public hostility against Communists extends to Smith Act defendants. While it might be argued that such community hostility has greatly diminished during the past year, there is little indication that this is true. See, c.g., recent statement of United States Attorney General Brownell that the Communist "conspiracy is conducting business as usual, if not on an intensified scale." Time, April 30, 1956, p. 20. Nor has the "Spirit of Geneva" been such that there no longer exists a "clear and present danger." United States v. Lightfoot, 228 F.2d 861, 870 (7th Cir.), cert. granted, 350 U.S. 992 (1956) ("the smiles have been replaced with scowls").

29. See, e.g., federal legislation: Subversive Activities Control Act of 1950, 64 STat. 987, 50 U.S.C. $\$ 781$ (1952); Communist Control Act of 1954, 68 STAт. 775, 50 U.S.C. $\$ \S 841-42$ (Supp. II, 1955); state statutes outlazuing the Communist Party: Ind. ANn. Stat. $\$ \$ 10-5201$ to -5209 (Burns Supp. 1953) ; Mass. ANn. Laws c. 264, $\$ \$ 16-23$ (Supp. 1955) ; Tex. Rev. Civ. Stat. Ann. art. 6889-3A (Vernon Supp. 1955) ; cxcluding Commurists from public office: LA. Rev. STAT. ANN. $\$ \$ 14.361-362$ (West Supp. 1954) ; Digest of the Public Record of Conmunisy in the United States 324-82, 427-30 (1955) (hereinafter cited as Digest of CoMnunisas); requiring non-Communist oaths: OkLA. Stat. AnN. tit. 15, \$\$ 36.1-.2 (West Supp. 1955) ; Digest of Consuunisar 431-34, 472-87; loyalty investigations: Bontecou, The Federal Loyalty-Security Progran (1953) and others of this series of Cornell Studies in Civil Liberty. See Stouffer, Communism, Con- 
indication exists that this hostility will diminish in the foreseeable future. ${ }^{30}$ The voir dire is thus the only device open to Smith Act defendants for assuring the selection of impartial jurors.

The voir dire examination has been considered an effective means of eliminating biased jurors, ${ }^{31}$ but where widespread community hostility exists against an accused, as in Smith Act cases, its value may be seriously impaired. The Supreme Court has consistently indicated that the right of an accused to an impartial jury is sufficiently protected by the opportunity voir dire affords to disclose a prospective juror's bias. ${ }^{32}$ However, it is doubtful whether the voir dire can effectively eliminate all biased veniremen. The voir dire operates as an exclusionary device, ${ }^{33}$ permitting each venireman to be questioned to determine "actual bias." 34 Thus its ultimate effectiveness depends on the degree to which questions asked will uncover bias. But a person aware of a prejudice will not readily admit to it under public questioning. ${ }^{35}$ And if his bias is unconscious, it may be even more difficult to detect. ${ }^{36}$ Assuming a given effec-

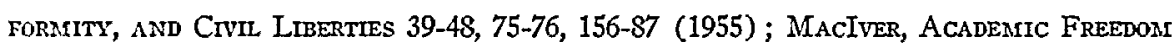
in Our Tine 34-44, 158-201, 312-15 (1955) ; Brbliography on the Comianonist Problem in THE UNITEd STATES (1955).

For evidence in Smith Act cases of the climate of opinion adverse to Communists, see, e.g., Appellants' Brief in Support of Challenge and Other Questions, pp. 63-96, United States v. Flynn, 216 F.2d 354 (2d Cir. 1954).

30. See, e.g., Wellman v. United States, 227 F.2d 757, 775 (6th Cir. 1955) (anti-Communist hostility not a temporary prejudice which could reasonably be expected to fade over a period of time) ; United States v. Flynn, 216 F.2d 354, 373-74 (2d Cir. 1954), cert. denied, $3+8$ U.S. 909 (1955) ; United States v. Dennis, 183 F.2d 201, 226 (2d Cir. 1950), aff'd, 341 U.S. 494 (1951).

31. See, e.g., Connors v. United States, 158 U.S. 408, 413 (1895) ; Scales v. United States, 227 F.2d 581, 592 (4th Cir.), cert. granted, 350 U.S. 992 (1956); State v. Hume, 146 Me. 129, 133-34, 78 A:2d 496, $499-500$ (1951) ; Kitts v. State, 153 Neb. 784, 792-93, 46 N.W.2d 15S, 163-64 (1951).

The discussion of the voir dire in this Note is limited to challenge for cause for bias, a determination within the sound discretion of the court. See 28 U.S.C. $\$ 1870$ (1952). On challenges generally, see Busce, op. cit. supra note 25 , $\$ \$ 67-154$.

32. See, e.g., Dennis v. United States, 339 U.S. 162, 168 (1950) ; Frazier v. United States, 335 U.S. 497, 509-11 (1948) ; United States v. Wood, 299 U.S. 123, 133-34 (1936) ; cf. Thiel v. Southern Pac. Co., 328 U.S. 217, 220 (1946) ("Jury competence is an individual rather than a group or class matter.").

33. See Hayes v. Missouri, 120 U.S. 68, 71 (1887) ; Buscr, op. cit. supra note 25 , \$ 72; Note, 58 Yale L.J. 638, 639 (1949).

34. See Dennis v. United States, 339 U.S. 162, 168 (1950).

35. Id. at 175-85 (dissenting opinions); BuscE, op. cit. supra note $25, \$ 141$; GoldSTEIN, TRIAl Technigue $\$ 236$ (1935); Nizer, The Art of the Jury Trial, 32 CoRNeLL L.Q. 59, 63 (1946). See also, Stevens v. State, 94 Okla. Crim. 216, 221-25, 232 P.2d 949, 955-59 (1951) (on voir dire examination juror denied prejudice which he clearly had).

36. Cf. "[A]ny examination on the voir dire is a clumsy and imperfect way of detecting suppressed emotional commitments to which all of us are to some extent subject, unconsciously or subconsciously. ... If trial by jury is not to break down by its own weight, it is not feasible to probe more than the upper levels of a juror's mind." United States v. Dennis, 183 F.2d 201, 227 (2d Cir. 1950), aff'd, 341 U.S. 494 (1951). See Note, The Right 
tiveness for the voir dire, the number of biased jurors chosen should increase in direct proportion to the percentage of biased veniremen on the panel. When only a minor percentage of the jury panel is biased, which is probably most often true, at most only a few biased jurors will be chosen because the usual effectiveness of the voir dire will eliminate a large portion of the biased panel members. When a large percentage, perhaps a majority, of the panel is biased against an accused because of widespread community hostility against him, the number of biased veniremen who become jurors will probably be significantly greater than in the usual criminal case. The existence of such hostility is the norm in Smith Act cases. ${ }^{37}$ It may thus be argued that defendants in these cases will be tried by juries with a substantial number of biased members unless they waive jury trial. ${ }^{38}$ Under these circumstances if the government can force jury trial on a defendant by arbitrarily withholding consent to waiver, the impartial jury requirement of the Sixth Amendment would be violated. ${ }^{30}$

to an Impartial Federal Jury in the Event of Prejudicial Pretrial Publicity, 53 CoLuM. L. REv. 651, 659 (1953).

Moreover, questioning on the voir dire is limited, another factor reducing its effectiveness to disclose bias. Under FED. R. CRIM. P. 24(a) the trial judge may examine the panel himself. Though counsel may suggest questions, the court's discretion in accepting them is usually controlling. See, e.g., Yarborough v. United States, 230 F.2d 56, 63 (4th Cir. 1956); Cwach v. United States, 212 F.2d 520, 531-32 (Sth Cir. 1954). And courts will not always allow extended interrogation. See, e.g., United States v. Mesarosh, 116 F. Supp. 345, 349 (W.D. Pa. 1953), aff'd, 223 F.2d 449 (3d Cir.), cert. granted, 350 U.S. 922 (1955). Informal questioning of veniremen by counsel in the judge's chambers might prove more satisfactory than formal court room examination. This procedure was recently used in a Smith Act case in the Southern District of New York. N.Y. Times, April 20, 1956, p. 27, col. 3 .

37. See note's 28,29 supra.

38. "Since . . . challenges . . . are merely rejection devices, their success must depend, in the last analysis, on the existence of a panel containing a high proportion of unprejudiced prospective jurors." Note, Selection of Jurors by Voir Dire Examination and Challenge, 58 Y ALE L.J. 638, 639 (1949). See also Note, Fair Trial and Biased Public Opinion, 3 SYRACUSE L. Rev. 150, 151, 153, 156 (1951).

The argument that Smith Act defendants are unable to secure impartial juries may be somewhat vitiated by recent acquittals. In United States v. Brandt, Crim. No. 21276, N.D. Ohio, Feb. 10, 1956, the jury acquitted four of the eleven defendants and a fifth was acquitted by directed verdict. Cleveland Plain Dealer, Feb. 11, 1956, p. 1, col. 3. Of the eight defendants in Silverman, the jury acquitted one and reached no verdict on another. See note 14 supra. However, of the 113 defendants tried by jury in "Communist" Smith Act cases up to April 1, 1956, 103 have been convicted, six acquitted, three acquitted by directed verdict, and no verdict reached on one. Enclosure No. 130162 to letter from William F. Tompkins, Assistant Attorney General, United States Dep't of Justice, to the Yale Law Joumal, March 23, 1956, on file in Yale Law Library; N.Y. Times, March 30, 1956, p. 19, col. 1.

39. The requirement of government consent under rule 23(a) foreshadows possible unfairness in other cases, for community passions can operate similarly to the disadvantage of any unpopular defendant. Cf. Frank v. Mangum, 237 U.S. 309, 349 (1915) (dissenting opinion) ("in spite of forms they [juries] are extremely likely to be impregnated by the environing atmosphere"). See also Joughin \& Morgan, The Legacy of Sacco and Vanzerri 191-97 (1948); Grant, Felony Trials Without a Jurry, 25 Ax. PoL. Scr. Rev. 980, 
The Second Circuit's opinion in Dennis v. United States, ${ }^{40}$ the first Communist trial under the Smith Act, ${ }^{41}$ does not necessitate a contrary conclusion. In Dennis the court held that a Smith Act defendant must be brought to trial even in the face of "heated public feeling against Communists" which might produce a biased jury. The court declared that a jury meets the standard of the Sixth Amendment if the best means available to secure an impartial jury have been used.42 Thus under the Dennis rationale the amendment guarantees a defendant an unbiased jury, but if such a jury is unavailable the most impartial jury obtainable will suffice. Since the defendants in the Dennis case did not seek to waive a jury, the alternative to jury trial was to allow the prosecution to lapse, an unacceptable solution. ${ }^{43}$ It was therefore necessary for the Dennis court to reach the conclusion it did.44 In Silverman, on the other hand, by waiver of a jury the defendants invoked the frequently employed alternative of trial by the court. ${ }^{45}$ The waiver consequently avoided the conclusion forced upon the Dennis court. It directly presented for decision the

991-92, 994 (1931) ; Comments, 14 Mo. L. Rev. 185, 189 (1949), 23 Rocky Mr. L. Rev. 334,335 (1951).

40. 183 F.2d 201 (2d Cir. 1950), aff'd, 341 U.S. 494 (1951).

41. Prior to the trial of "first string" Communists in Dennis, there were only two prosecutions under the Smith Act: Dunne v. United States, 138 F.2d 137 (8th Cir.), cert. devied, 320 U.S. 790 (1943) (conviction of Socialist Workers Party members) ; United States v. Larremore (S.D. Cal. 1941) (unreported). Letter from William F. Tompkins, Assistant Attorney General, United States Dep't of Justice, to the Yale Law Journal, March 23, 1956, on file in Yale Law Library. For discussion of the Smith Act and prosecutions thercunder, see Digest of Commounism 194-205; Note, 31 Ind. L.J. 104 (1955).

42. 183 F.2d at 226 .

43. Ibid. Cf. "[T]his danger [of hostility toward Communists] is one of the risks run in a trial by jury; and the defendants made no effort to procure a trial by judge alone, under Criminal Rule 23(a)." United States v. Rosenberg, 195 F.2d 583, 596 (2d Cir.), cert. denied, 344 U.S. 838 (1952).

44. The court's ruling was justified by a doctrine of necessity which has been applied in analogous situations. Hearings before administrative bodies have been upheld in the face of a party's charge of bias if no other agency was provided by statute to decide a case. See, e.g., United States v. Morgan, 313 U.S. 409, 420-21 (1941) ; Marquette Cement Mfg. Co. v. FTC, 147 F.2d 589, 593-94 (7th Cir. 1945), aff'd, 333 U.S. 683, 700-03 (1948); Brinkley v. Hassig, 83 F.2d 351, 357 (10th Cir. 1936). But a hearing before a biased agency violates due process if an alternative tribunal is available. See, e.g., NLRB v. Phelps, 136 F.2d 562 (5th Cir. 1943).

And necessity has permitted proceedings before courts charged with bias if no other tribunal was available. See, e.g., Evans v. Gore, 253 U.S. 245, 247-48 (1920); State ex rel. Gardner v. Holm, 241 Minn. 125, 126, 62 N.W.2d 52, 54 (1954). See Annot., 39 A.L.R. 1476 (1925).

45. Waiver is common in the federal courts. During the 1955 fiscal year, for example, of 4087 criminal trials in federal courts, 1349 were court trials. Letter from Will Shafroth, Chief, Div. of Procedural Studies and Statistics, Administrative Office of the United States Courts, to the Yale Law Journal, Oct. 28, 1955, on file in Yale Law Library. See also Judicial Council of Michigan, Twenty-Fourth Annual Report 46 (1954); Judiclal Council of tee State of NEW York, Fifth ANnual Report 174-78 (1939) (hereinafter cited as N.Y. RePorT). 
issue of the jury's bias and the constitutionality of the government's arbitrary withholding of consent under rule $23(\mathrm{a})$.

The court in Silverman should therefore have explicitly decided whether an impartial jury was obtainable, for under the court's interpretation of the rule this finding was necessary to determine its constitutionality in the case. The court made no such finding; presumably, in accord with Dennis, it considered that the jury would be sufficiently impartial as long as it were chosen by the best means available. However, after the Silverman defendants moved for court trial, the real issue was whether an unbiased jury was obtainable at all. A finding that any jury would probably be biased would have required granting the defendants' motion for waiver, ${ }^{46}$ for denial of waiver under these circumstances would also deny the right to an impartial jury. Consequently, the court's view that rule 23(a) allows the government to withhold consent arbitrarily would have made the rule unconstitutional in Silverman had the jury bias issue been decided in favor of the defendants.

Rule 23 (a) could have been interpreted to allow government consent to be only reasonably withheld. This reading of the rule would save its constitutionality in Silverman, for if the court determined the jury bias issue favorably to the defendants government refusal to consent would be clearly unreasonable. On the other hand, if the court decided differently on the bias question, it would then evaluate the government's reasons for refusing consent. Admittedly, cases dealing with the issue of a defendant's waiver of jury before rule 23(a) was promulgated allowed government consent to be arbitrarily withheld. ${ }^{47}$ And it could justifiably be argued that the rule was meant to follow these decisions. But the Patton opinion, from which the rule is derived, does not compel this interpretation. Along with the dictum declaring the need for government consent to waiver, Patton stated that the decision on waiver should rest with an accused.48 Moreover, when the Supreme Court later cited the dictum approvingly, it also reiterated the view of Patton that the defendant should be permitted to determine the form of trial. ${ }^{49}$ In adopting rule 23(a), therefore, the Court might have intended to empower the government to prevent waiver of jury only where it gave reasonable grounds for refusing con-

46. The court's finding on the jury's probable bias should be made prior to the voir dire examination. Presumably the finding would be based on affidavits, direct testimony or other evidence offered at a hearing on the issue. See, e.g., Delaney v. United States, 199 F.2d 107, 111 (1st Cir. 1952).

47. See cases cited note 21 supra.

48. See notes 19,20 supra.

49. See Adams v. United States ex rel. McCann, 317 U.S. 269, 275-80 (1942). Adains indicates that trial by jury is a right which an accused should be able to waive at will: "And since trial by jury confers burdens as well as benefits, an accused should be permitted to forego its privileges when his competent judgment counsels him that his interests are safer in the keeping of the judge than the jury." Id. at 278; "[A]n accused, in the exercist of a free and intelligent choice, and with the considered approval of the court, may waive trial by jury." Id. at 275 . Yet the Patton dictum requiring government consent was acknowledged, $i d$. at $277-78$, and the government had consented to the waiver. 
sent. In addition, the government's arbitrary withholding of consent did not pose a constitutional issue in any of the earlier cases. Until Silverman, therefore, no conflict with a constitutional right arose to invite a different reading of the rule. But Silverman presented a situation in which the rule could operate unconstitutionally if the interpretation that government consent is mandatory were followed. The suggested interpretation would obviate this possibility and would accord with the rule of statutory construction favoring avoidance of constitutional issues where possible. ${ }^{50}$

An argument which the government might have employed for refusing consent to waiver is that a "public interest" in trial by jury exists which must be protected. This argument would carry no weight if the court upheld the defendants' position on the jury's probable bias. The contention that the public has an interest in conducting trials by jury rests on the theory that the jury will protect an accused from unfounded conviction. ${ }^{51}$ But when it is probable that the jury will be biased against an accused, he would be harmed, not aided, by jury trial. Assuming the court in Silverman decided against the defendants on the bias issue, the public interest argument should still be rejected if the court found that the defendants had intelligently waived the protection the jury was meant to provide. A defendant's intelligent waiver weakens the public interest argument. Such waiver reflects the defendant's considered decision that the court would provide a fair trial. Furthermore, by allowing an accused to plead guilty and thus reject a jury's protection entirely, federal criminal law indicates that little weight is actually accorded to this ground for requiring government consent. ${ }^{52}$

Apart from the constitutional issue raised in Silverman, the decision whether trial is to be by a jury or before the court should rest solely with an accused. ${ }^{53}$

50. See, c.g., United States v. CIO, 335 U.S. 106, 120-21 (1948); Anniston Mfg. Co. v. Davis, 301 U.S. 337, 351-52 (1937) ; United States v. La Franca, 282 U.S. 568, 574 (1931).

51. See, e.g., Hopt v. Utah, 110 U.S. 574, 579 (1884) ("The public has an interest in [an accused's] ... life and liberty.") ; State v. Ricks, 173 Kan. 660, 664, 250 P.2d 773, 777 (1952) ; Cancemi v. People, 18 N.Y. 128, 137-38 (1858).

52. In Patton the public interest argument was rejected as an unsound reason for refusing waiver, 281 U.S. at $302-08$, on the ground that defendant may dispense with a trial altogether by a plea of guilty. See FED. R. CRIM. P. 11. But see Perkins, Proposed Jury Changes in Criminal Cases, 16 Iowa L. REv. 20, 22 (1931). For discussion and refutation of the public interest theory, see Oppenheim, Waiver of Trial by Jury in Criminal Cases, 25 MicH. L. Rev. 695, 710-17 (1927).

53. This is the conclusion of the American Law Institute. ALI Code of CRIMINal. Procedure $\$ 266$ (1930). Various commentators have stated that consent of court and government should not be required. See, e.g., Orfield, Criminal Procedure from Arrest TO APPEAL 393 (1947) ; N.Y. REPORT 166; Grant, Waiver of Jury Trials in Felony Cases, 20 CAlif. L. REv. 132, 161 (1932) ; Oppenheim, supra note 52, at 736. See also Stewart, Comments on Federal Rules of Criminal Procedure, 8 JoHN Marshali L.Q. 296, 301 (1943).

Conceivably it could be argued that a statute permitting an accused to waive jury trial at his discretion would be a legislative infringement on judicial power. But since the 
Rule 23(a) should be revised to eliminate entirely the need for government consent to waiver and to require court approval only as assurance that waiver has been intelligently made. ${ }^{54}$ Two arguments have been advanced to support the present rule: the constitutional right of an accused to jury trial must be jealously guarded, and the jury traditionally holds an important place in criminal law as a fact-finding body. ${ }^{55}$ Neither argument justifies a rule that allows the government to prevent trial by the court. That the right of an accused to a jury should be carefully guarded is axiomatic. But requiring a waiver which the court believes to be intelligently made would sufficiently protect the defen-

Federal Rules of Criminal Procedure are promulgated by the Supreme Court, such an objection probably would be obviated on the federal level. Nor does the "separation of powers" argument have substantial merit in preventing such legislation by the states. See, for example, the history of waiver in Illinois as reflected in the following cases: People $c x$ rcl. Swanson v. Fisher, 340 I11. 250, 172 N.E. 722 (1930) ; People v. Scornavache, 347 IIl. 403, 179 N.E. 909 (1931) ; People v. Scott, 383 I11. 122, 48 N.E.2d 530 (1943) ; People v. Spegal, 5 I11. 2 d 211, 125 N.E.2d 468 (1955), 33 CHI.-KeNT L. Rev. 379 (1955).

54. Some states allow waiver of jury by an accused without either government or court consent. See, e.g., Ill. Rev. Stat. c. 38, \$ 736 (1955), People v. Spegal, supra note 53, at 120-22, 125 N.E.2d at 472-73; Mich. Stat. ANn. \$ 28:\$56 (1954), People v. Martin, 256 Mich. 33, 35, 239 N.W. 341 (1931) ; Oнro Rev. Code ANN. \$ 2945.05-.06 (Page 1954), State v. Smith, 123 Ohio St. 237, 240-41, 246-48, 174 N.E. 768, 770-72 (1931) ; cf. La. Rev. Stat. Ann. \$ $15: 342$ (1951); Minn. Stat. Ann. \$ 631.01 (1947); Utah Cone ANN. \$ 77-27-3 (1953).

But both court approval and government consent to waiver are required by, c.g., IND. Ann. Stat. \$ 9-1803 (Burns 1942), State ex rel. Rose v. Hoffman, 227 Ind. 256, 262, 85 N.E.2d 486, 488 (1949) ; Kan. Gen. Stat. ANn. \$ 62-140 (1949), State v. Ricks, 173 Kan. 660, 664-65, 250 P.2d 773, 777 (1952) ; PA. Stat. Ann. tit. 19, \$ 786 (Purdon Supp. 1954), Commonwealth ex rel. Henderson v. Kruger, 119 A.2d 870, 872 (Pa. Super. 1956) ; VA. Code ANN. \$ 19-166 (Supp. 1954); Wis. STAT. § 357.01 (1953).

Some states, while not requiring consent of the prosecutor, require court approval of waiver. E.g., Mo. Const. art. 1, \$ 22(a), Mo. Sup. CT. (Crni.) Rule 26.01 (a), Comment, 14 Mo. L. Rev. 185 (1949); Wast. Rev. Code $\$ 10.01 .060$ (1952).

Except to assure that defendant made an intelligent choice, knowing of his rights, sce State v. Ellard, 95 N.H. 217, 222, 60 A.2d 461, 465 (1948), cert. denied, 335 U.S. 904 (1949) ; cf. Dillingham v. United States, 76 F.2d 36, 39 (1935) (conviction reversed because waiver made without full understanding of rights), there is little more reason to require court approval than government consent to waiver. See commentaries cited note 53 supra. For discussion of jury waiver in state criminal cases, see Busch, op. cit. supra note $25, \$ \S 46-47$; Grant, Waiver of Jury Trials in Felony Cases, 20 CALIF. L. Rev. 132, 135-46 (1932) ; Oppenheim, supra note 52, at 699-733; Perkins, supra note 52, at 22-49.

55. See Patton v. United States, 281 U.S. 276, 312 (1930). It has also been suggested that the state has acquired a right to jury trial. See, e.g., People' v. Scornavache, 347 Ill. $403,416,179$ N.E. 909,914 (1931) ("The long recognition by courts everywhere that trial in a criminal case means a jury trial has clearly given to the people the right to object to a trial by the court on waiver of a jury trial by the accused."), criticized in 27 IxL. L. REv. 447 (1932). See also State v. Mead, 4 Blackf. 309 (Ind. 1837) ; State cx rcl. Gutierrez v. First Judicial Dist. Ct., 52 N.M. 28, 32-33, 191 P.2d 334, 337 (1948). For criticism and rejection of this view, see Hall, Has the State a Right to Trial by Jury in Criminal Cases?, 18 A.B.A.J. 226, 227 (1932). See also People v. Spegal, 5 I1l. 2d 211, 125 N.E.2d 468 (1955), overruling Scomavache, supra. 
dant. ${ }^{60}$ Furthermore, trial by jury was considered solely a defendant's safeguard against arbitrary government prosecution ${ }^{57}$ when the Constitution and the Bill of Rights were adopted. ${ }^{58}$ No evidence exists that the government

56. See Grant, Felony Trials Without a Jury, 25 Ax. Por. Scr. Rev. 980, 994-95 (1931).

Furthermore, it is questionable whether the government may be relied upon to protect a defendant's rights. While it is generally stated that the prosecuting attorney's function is not to convict but to see that justice is done, see, e.g., Berger v. United States, 295 U.S. $78,8 S$ (1935), in practice the desire for a verdict of guilty may substantially weaken his role on behalf of an accused. Jougrin \& MoRgan, op. cit. supra note 39, at 185-89. Cf. "It is irony indeed, that ... the tribunal which for centuries was regarded as the safeguard and protection of the accused, can now . . be employed by the State to facilitate conviction." Hall, supra note 55, at 227.

57. Such was not always true, however. The modern jury evolved from inquests employed by Norman and Angevin kings to obtain information. Haskins, Noriran InsTTtutrons 196 (1918) ; 1 Pollock \& Maitland, History of English Law 74, 140-41 (2d ed. 1899). The Statute of Westminster, 1275, 3 EDw. 1, c. 12, indicates that jury trial was not always beneficial to the accused. It provided that felons refusing to go to trial were to be put into a "prison forte et dure," transformed in common speech to "peine forte et dure." By the sixteenth century this phrase came to mean the form of torture whereby prisoners were crushed until they accepted jury trial or died. Plucknetr, A Concise History of the Consaron Law 121-22 (4th ed. 1948); 1 . Stephen, A History of the CrniNar. Law of England 298-99 (1883). Not until Bushell's Case, Vaugh. 135, 124 Eng. Rep. 1006 (C.P. 1670), were jurors freed from fines and imprisonment for reaching a verdict contrary to the court's instructions. On the history of jury trial generally, see 1 Holdsworth, A History of ENGLIs L Law 298-347 (6th ed. 1938) ; Plucknetr, op. cit. supra at 104-30; Thayer, A Preliminari Treatise on Evidence 1-182 (1898).

Whatever the early history of the jury, by the eighteenth century it was considered an important English right for the benefit of the accused. See, e.g., 3 BLACKSTONE, COMrMENTARIES *379, *381. ("the glory of the English law", "this best preservative of English liberty") ; CARe, ENGlish LIBERTY 22, 200-03 (5th ed. 1721); J[ACoB], The LAws of LIBERTY AND PROPERTY 31 (2d ed. 1734); [Somers], The Security of Englishmen's Lives, in A Guide to the Kwowledge of the Rights and Printeges of Englishinen 148-52 (1757). See also Maitland, Outlines of English Legal History, 560-1600, in 2 Coldected PAPERS 445 (1911).

58. See United States $e x$ rel. Toth v. Quarles, 350 U.S. 11, 16 (1955) ; Patton v. United States, 281 U.S. 276, 296-98 (1.930) ; People v. Scornavache, 347 I1l. 403, 409-12, 179 N.E. 909, 911-12 (1931).

Trial by jury was clearly considered a benefit for the accused in the colonies. Trials in vice-admiralty courts without juries, for example, caused colonials to protest they were being deprived of an English liberty. 4 Andrews, The Colontal Period of Amrerican HistoRY 224, 258, 263 n.1, 270 (1938). Various public documents voiced this objection. See, e.g., 1 The Papers of Thomas Jefrerson 214, 378, 431 (Boyd ed. 1950). For discussion of jury trial in the colonies see HeILER, THE Sixth AMIENDMEnt 13-34 (1951).

Records indicate little discussion of jury trial at the constitutional convention. See 2 Farraind, The Records of the Federal Convention of 1787 at 144, 173, 187, 434, 438, 587, 628 (2d $\in d$. 1937). But see, e.g., 3 id. at 101, 221. And the debates on the Bill of Rights clearly indicate that trial by jury was for the benefit of the accused. See, e.g., 1 ANNALs af Congress 452-55, 458, 783-85, 788-89 (Gales ed. 1834) ; Rutrand, The Birth of the Bill of Rights 1776-1791 passin (1955). See also 3 Story, Comimentaries on the Constitution of THE UNITED States $\$ \$ 1773-74$ (1833). 
was meant to have a right or interest in jury trial. ${ }^{59}$ The argument based on the jury's role as a fact-finding body is equally unimpressive. The extensive use of rule 23(a) itself indicates that the jury is no longer indispensable for this purpose. ${ }^{60}$ The only objection to trial by the court without government consent is the possible bias of the judge against the prosecution or for the defendant. Protection is afforded against this possibility by the procedure for disqualifying federal judges. ${ }^{61}$

59. N.Y. REPORT 166; see authorities cited note 58 supra. But see note 55 supra.

60. See note 45 supra. Even before rule $23(a)$, trial by the court was used in some federal districts. See, e.g., discussion of waiver in the Middle District of Pennsylvania in Grant, Felony Trials Without a Jury, 25 Am. PoL. Scr. Rev. 980, 985-86 (1931). For criticism of the jury as a fact finder, see Frank, Courts on Trual 114-27 (1950) ; Broeder, The Functions of the Jury, Facts or Fictions?, 21 U. CHI. L. REv. 386, 387-401, 413-17 (1954).

The relative merits of jury and court trial have been much debated during the past century. For a summary of the various arguments, see memorandum by Professor Harry Kalven, Jr., University of Chicago Law School, in Hearings Before the Sibcommittce to Investigate the Administration of the Internal Security Act and Other Internal Security Laws of the Senate Committee on the Iudiciary, 84th Cong., 1st Sess., at 63-81 (1955). For lists of materials on juries, see HeLLER, op. cit. supra note 58, at 178-88; Hill, Selectcd List of Materials on Juries, 4 THE RECORD OF THE Ass'N OF THE BAR OF THE CITY OF NEw YoRK 139 (1949). The debate has generally been in terms of jury trial in civil cases. See Frank, op. cit. supra at 145; Corbin, The Jury on Trial, 14 A.B.A.J. 507, 508 (1928). But much of the criticism is equally applicable to juries in criminal trials. Broeder, supra at 417 .

61. 28 U.S.C. $\$ 144$ (1952) (disqualification for bias or prejudice). Relief under this section is limited, for a party may file only one affidavit of bias or prejudice in any case. And there is indication that the section is not very effective. Frank, Disqualification of Judges, 56 Y ALE L.J. 605, 629-30 (1947) ; Schwartz, Disqualification for Bias in the Fcderal District Courts, 11 U. PITT. L. Rev. 415, 418-29 (1950). But the remedy is not to give the government a power to insist on jury trial. Instead the disqualification procedure should be strengthened. 